\section{Is cork oak (Quercus suber L.) woodland loss driven by eucalyptus plantation? A case- study in southwestern Portugal}

\author{
Augusta Costa ${ }^{(1)}$, Manuel Madeira ${ }^{(2)}$, José Lima Santos ${ }^{(2)}$
}

\begin{abstract}
Mediterranean landscapes with open cork oak (Quercus suber L.) woodlands have recently experienced drastic changes in southwestern Portugal. Changes in agricultural activities, the traditional driver of the economy in this region, led to new land uses, such as long-term set aside (shrublands) and eucalyptus plantations. A study was conducted on the oak woodland landscape dynamics over a 50-year period (from 1958 to 2007) in order to assess the effect of different biophysical conditions on landscape spatial changes, and to identify the resilience of lanscape composition to different disturbances (e.g., socio-economic changes and wildfires). Land use changes over two consecutive periods (1958-1995 and 1995-2007) were inferred by spatial analysis of land cover data (aerial photographs) and related to landscape physical attributes (slope and soil type). A transition matrix of four vegetation land-cover classes was obtained, allowing the assessment of the landscape composition changes bewteen the two above periods. Results showed that lansdcape in 1958 was largely occupied by open farmland, with large patches of open oak woodlands on steep slopes surrounding watercourses. Open farmland and shrubland drastically declined from 1958 to 1995 , while eucalyptus plantation exhibited a dramatic expansion. Although large areas of cork oak forest turned into eucalyptus plantation, the net loss of oak forest was low and counterbalanced by its increment on former open farmland. The occurrence of a wildfire in 2003 promoted a dramatic decrease in cork oak woodlands, which mostly turned into shrubland. However, shrubland may be considered "safe sites" for ecological succession, ensuring natural cork oak regeneration and the colonisation of neighboring areas.
\end{abstract}

Keywords: Mediterranean Climate Region, Evergreen Oak Woodlands, Quercus suber L., Agroforestry Systems, Land Cover, Eucalyptus Plantations

\section{Introduction}

Landscapes with cork oak (Quercus suber L.) in southwestern Iberia (called montados in Portugal, dehesas in Spain) are cultural (wood-pastures) human-shaped landscapes, as defined by Manning et al. (2006). Despite strong disturbances caused by changes in human activity, these open woodland ecosystems mimic natural ecosystems (Joffre et al. 1999, Pereira \& Fonseca 2003). Their high biodiversity (Bugalho et al. 2011) contributes to the heterogeneity of the landscape mosaic, including (open) woodlands, shrublands, and open farmland (Vallejo et al. 2006), and to the existing nested, multifunctional spatial structure, as characterized by Santos \& Thorne (2010).

In the last 50 years, imminent multiple changes, including agricultural conversion and new forest plantations (Martínez et al.
(1) Center for Environmental and Sustainability Research (CENSE), Faculdade de Ciências e Tecnologia, Universidade Nova de Lisboa, Campus de Caparica, 2829-516 Caparica (Portugal); (2) Centro de Estudos Florestais (CEF), Instituto Superior de Agronomia, Universidade de Lisboa, Tapada da Ajuda, 1349-017 Lisboa (Portugal)

@ Augusta Costa (augusta.costa.sousa@gmail.com)

Received: Apr 30, 2013 - Accepted: Oct 19, 2013

Citation: Costa A, Madeira M, Lima Santos J, 2014. Is cork oak (Quercus suber L.) woodland loss driven by eucalyptus plantation? A case-study in southwestern Portugal. iForest 7: 193203 [online 2014-02-17] URL: http://www.sisef.it/iforest/contents/?id=ifor1031-007

Communicated by: Agostino Ferrara
2010), have drastically affected the sustainability of Mediterranean woodland ecosystems, leading to their classification as at-risk native biodiversity hotspots (Myers et al. 2000). Assessment of the dynamics of these landscapes and the identification of the driving factors responsible for the current change processes are thus strongly needed.

Recent changes reported for cork oak woodland landscapes were mainly related to stressful environmental conditions (e.g., soil type and hydrological regime - Costa et al. 2008, 2010), disturbance regimes (e.g., wildfire occurrence - Moreira et al. 2001), vulnerable agricultural economy (changing the incentive structure of successive Common Agricultural Policy reforms of the European Union), and labor force availability (PintoCorreia 2000, Plieninger 2006, Costa et al. 2011). These changes usually result in: (i) a more intense land use (e.g., higher grazing pressure, modern permanent-crop farming systems, or eucalyptus plantations); and (ii) an extended land use (e.g., shrubland encroachment in set-aside or burnt areas); and, therefore, (iii) a shift from the traditional multifunctional landscape to different singlefunction landscapes.

Information on oak woodland landscape dynamics has been reported in Spain for cork oak and holm oak (Quercus ilex) dehesas (Cano et al. 2003, Plieninger 2006), and for mixed forests of cork oak and Algerian oak (Quercus canariensis - Urbieta et al. 2008), which emphasized the effect of environmental factors (climate and physiographical conditions) on oak woodland mosaic shifts. In California, for Quercus spp. woodlands, Huntsinger \& Bartolome (1992) and Santos \& Thorne (2010) concluded that different combinations of management intensities decisively affected oak woodland restoration and conservation. For southern Portugal, shifting rates and patterns of cork oak woodlands have been reported by Acácio et al. (2009), Costa et al. (2009, 2011) and Costa \& Madeira (2011). In these studies, changes in oak woodland landscapes always result in effective net losses of open farmland and cork oak woodlands, and in an expansion of forest plantations (pine and eucalyptus) or shrubland. However, none of the aforementioned studies analyzed where and how oak woodland landscapes change spatially, i.e., the relationships between change rates (and the transition matrices occurring in the landscape) and the biophysical characteristics of the landscape, such as slope or soil type. Moreover, no study has reported so far the landscape changes driven by different disturbances (e.g., land-use changes or wildfires) in Mediterranean regions.

Within this context, a study was carried out in the Ulme (UL) civil parish (Chamusca municipality, Portugal) where eucalyptus 


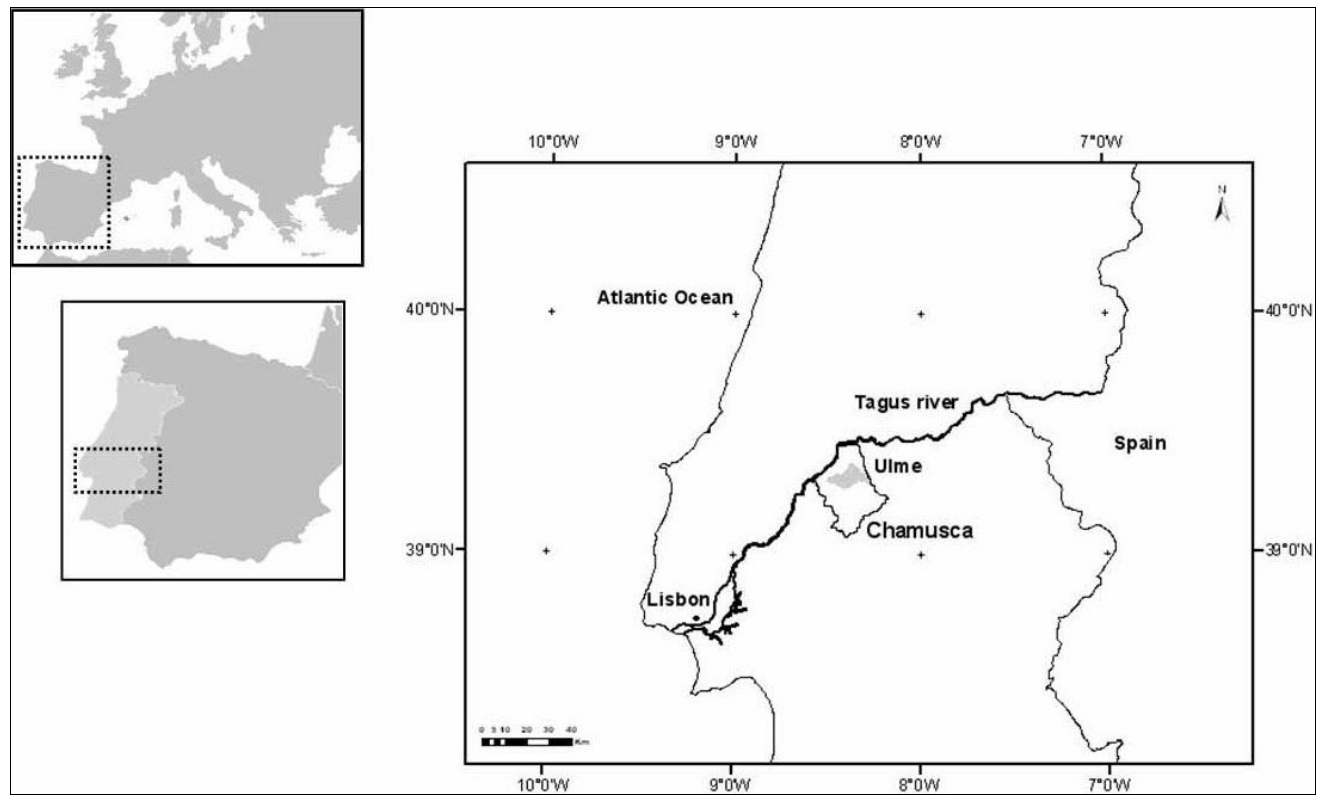

Fig. 1 - Location of the study area (Ulme civil parish, in light grey) in the Chamusca municipality (Portugal).

plantations currently cover about $30 \%$ of the total area, aiming to obtain a deeper understanding of the long-term (50-year) dynamics of the oak woodland ecosystem landscape. Our goals were to characterize at the local scale the changing pattern of landscapes with cork oak woodlands across different biophysical and socio-economic conditions, as well as to monitor land use shifts driven by wildfires, in order to assess the relationships between landscape pattern changes and their driving forces, as well as to identify emerging trends in the land use. Firstly, it was hypothesized that under different combinations of landscape attributes (e.g., slope or soil type), cork oak woodlands may be differently affected by disturbances, such as eucalyptus plantations expansion and wildfires. Slope, rather than soil type, should be decisive for cork oak woodland conservation and, therefore, it should be considered the prominent feature of cultural (humanmodified) oak landscapes. Furthermore, it was hypothesized that cork oak woodland landscapes would be differently resilient to distinct disturbances, such as the relatively slow response to eucalyptus plantations expansion (driven by socio-economic conditions) and the abrupt response to wildfires. As cultural landscapes are inherently less resilient to long-standing socio-economic drivers (Plieninger \& Bieling 2012), the UL's landscape should be less resilient to land use changes such as eucalyptus plantation expansion, driven by socio-economic changes, than to sudden disturbances such as wildfires.

\section{Material and methods}

Study area

The study area corresponds to the UL civil parish, which occupies 12179 ha and is located in southern Portugal $\left(39^{\circ} 23^{\prime} \mathrm{N}-08^{\circ}\right.$ $30^{\prime} \mathrm{W}$ and $39^{\circ} 16^{\prime} \mathrm{N}-08^{\circ} 15^{\prime} \mathrm{W}$ ), within the Tagus basin, about $100 \mathrm{~km}$ northeast of Lisbon (Fig. 1). The climate is of Mediterranean type, smoothed by the influence of the Atlantic Ocean (dry-sub-humid zone - IA 2010), with the highest temperatures during summer when rainfall is the lowest. The mean annual temperature is $16.5^{\circ} \mathrm{C}$; annual rainfall is between 700 and $800 \mathrm{~mm}$; and air humidity is between 66 and $81 \%$. Rainfall mostly occurs from late autumn to early spring, with great annual irregularities. In the last 50 years (1960-2010), the annual precipitation strongly varied between consecutive years and prolonged periods with below-mean values have been observed since 1970 (Costa \& Madeira 2011).

The study area is adjacent to the Tagus alluvial area and approximately corresponds to the UL river basin (Fig. 2). Elevation ranges from 20 to $190 \mathrm{~m}$ a.s.l. (Fig. 2A) and plateaus are densely carved by watercourses, in some cases associated with active gullies; therefore, the landscape is flat or gently undulating in both valleys bottom and elevated top areas, but steep along the slopes of watercourses (Fig. 2A). The geology is mostly related to the characteristic sedimentary formations of the Tagus basin (Gonçalves et al. 1979). Pliocene formations occupy flat or gently undulating areas (with slopes $<5 \%$ ) of elevated top areas (Fig. 2B and Fig. 3A). In contrast, Miocene formations occur in steeper areas, mostly along watercourses, and are dominant close to the Tagus alluvial area. Pleistocene alluvial terraces underlie Miocene formations at different altitudes, along the UL river. In the bottoms of valleys, recent Holocene alluvial areas often occur (Fig. 3A).
The predominant soils in the valley bottom (alluvial areas) are Fluvisols (sensu WRB 2006 - Fig. 3B). Soils occurring on flat top areas (Pliocene terraces) are mostly Stagnic Luvisols, sometimes associated with Regosols and Cambisols, and their main use is limited by low drainage (SROA 1972a, 1972b). Soils occurring in steep areas (mostly Miocene formations and Pleistocene alluvial terraces) are predominantly Regosols and Cambisols, associated with Stagnic Luvisols (Fig. 2 and Fig. 3), and erosion risk is their main limitation (SROA 1972a, 1972b). Therefore, Stagnic Luvisols are not only confined to flat or gently undulating areas with Pliocene formations, but also occur in undulating areas associated with Miocene formations, which are possibly related to the complex lithological composition of these formations.

The study area is within the natural potential vegetation area of the Asparago AphylliQuerco suberis $S$. vegetation series corresponding to the thermomediterranean to low mesomediterranean thermotypes and to the subhumid to humid ombrotypes (Capelo et al. 2007). A large area in UL was recently affected by wildfires. According to the Burnt Area Map of Portugal (AFN 2010), an area of 8108 ha was burnt in the period 20012005 , with a large wildfire affecting 8079 ha occurred in 2003 (Fig. 2B). This allowed us to consider two areas (burnt and unburnt - Fig. 2B) for which the landscape composition dynamics were analyzed independently between 1995 and 2007.

\section{Methodology}

Woodland landscape analysis was carried out for three dates: (i) 1958, when the first aerial photographs were produced for the area under investigation; (ii) 2007, when the 
Fig. 2 - Biophysical characteristics of the study area. (A): Elevation classes (m a.s.1.); (B): Slope classes (in \%). The black line separates the burnt (left) and unburnt (right) areas after the 2003 wildfire.

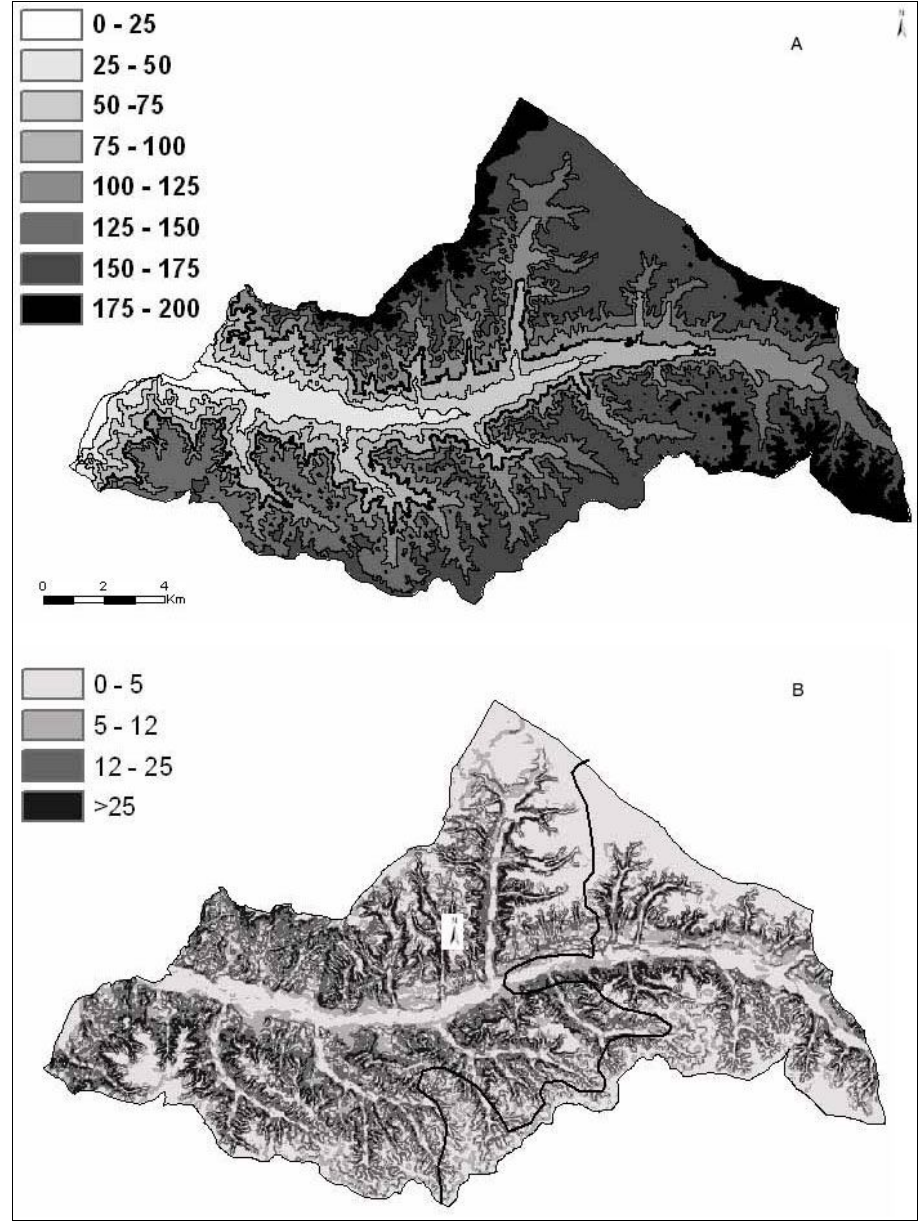

Fig. 3 - (A) Geologic formations in the study area: Alluvial (white), Pliocene (light grey), Miocene (dark grey), Pleistocene alluvial terraces (black and white strikes). (B) Dominant soil types:

Fluvisols (white); Stagnic Luvisols (light grey), Regosols and Cambisols (dark grey); Urban areas (black).

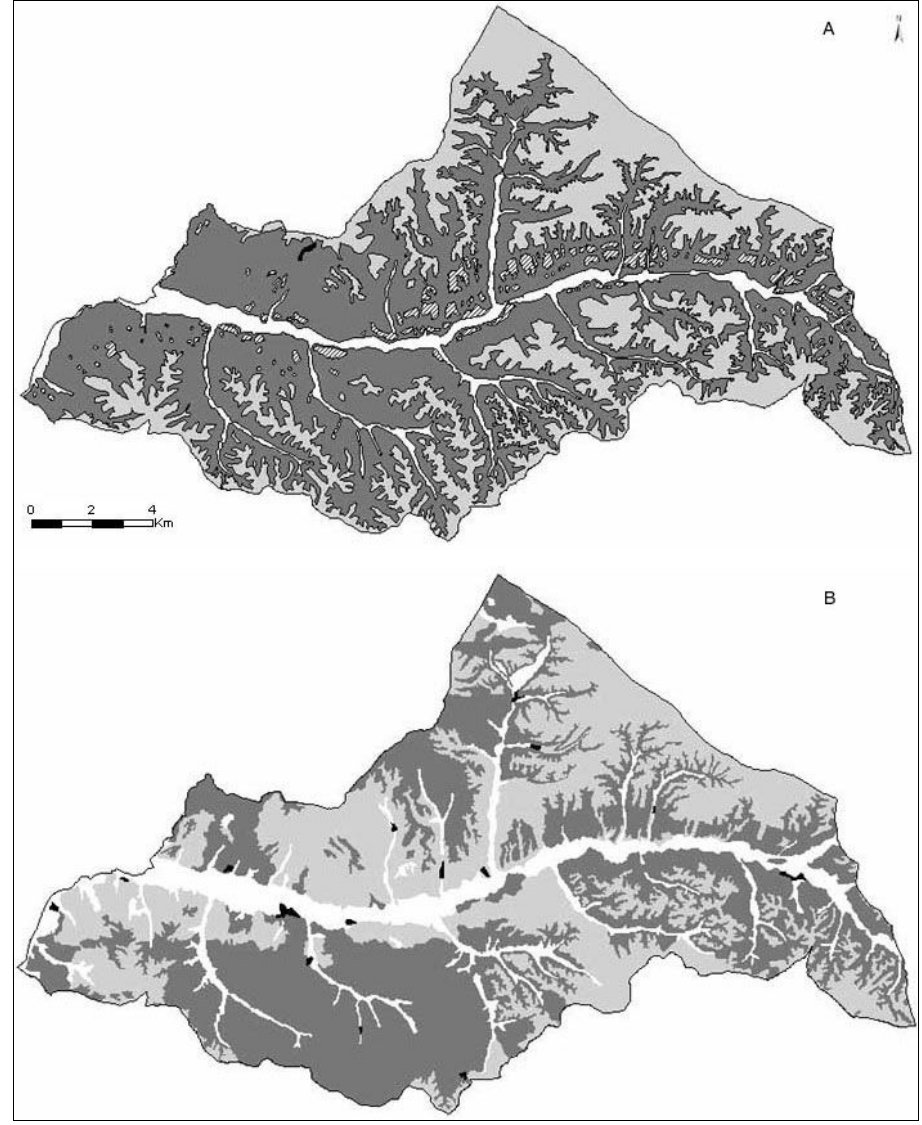


last aerial photographs of the same area were available; and (iii) an intervening year (1995) was also considered to obtain data on landscape changes in two consecutive periods (1958 to 1995,1995 to 2007). The 1990s are considered a turning point for the emergence of new oak afforestation areas (Mendes \& Dias 2001), given the increasing financial support for oak forest in the large private forest estates of southern Portugal Indeed, the full entry of Portugal to the European Union (in 1986) allowed eligibility for financial support from structural funds and agri-environmental schemes for multiple-use forestry which promoted new largescale oak afforestation activities (Mendes et al. 2004).

In 1995 and in 2007, the national aerial photography plans (at the Portuguese Geographic Institute) captured color near infrared, ortho-rectified, digital aerial photographs, with a spatial resolution of 1.0 and 0.5 $\mathrm{m}$, respectively. The aerial photographs of 1958 (panchromatic, $23 \times 23 \mathrm{~cm}, 1: 26000$ scale, commissioned by the Portuguese Geographic Army Institute) were scanned at medium resolution $(800 \mathrm{dpi})$, ortho-rectified using ERDAS IMAGINE ${ }^{\circledR}$ on a single-image basis (accessed through the software's Image Geometric Correction suite), with a positional accuracy of $<5 \mathrm{~m}$. Each 1958 aerial photograph was orthorectified using the digita ortho-images from 2007 as reference images and a minimum of six control points: it was difficult to find more than eight control points on the 1958 aerial photographs, where only few static elements could be found in sparsely settled areas. Ortho-rectified pictures were then re-sampled using a first-degree polynomial transformation and the nearest-neighbor interpolation algorithm. All images were projected onto the SHG73 System based on Gauss Transverse Mercator projection, ellipsoid of Hayford and Local Datum73.

A comparative analysis of UL's cork oak woodland landscape composition changes was carried out for areas markedly different as for the biophysical features (e.g., soil and slope). To this purpose, four vegetation landcover classes were considered based on the definitions of the National Forest Inventory (DGRF 2007): (i) open farmland (arable and permanent pastures, i.e., rain-fed areas with herbaceous vegetation, orchards, or olive groves, where tree density was lower or equal to five trees per ha); (ii) shrubland (areas dominated by shrub species, i.e., with a high woody plant cover, where tree density was lower or equal to five trees per ha); (iii) cork oak forest (tree density over five trees per ha); and (iv) eucalyptus forest. In this study, cork oak woodland landscape composition comprised a mosaic of open farmlands, cork oak forests and shrublands. Other vegetation types (coniferous forests and different broad-leaved forests) and non-vegetation areas (such as water bodies and urban areas) were grouped into the cover class "others". The minimum mapping unit area was 1.0 ha per patch for all classes.

The categorical map of the study areas in 2007 was first digitized to create a polygon layer derived from the photo interpretation. Patches were delineated to a minimum size of $1 \mathrm{ha}$, based on within-patch uniformity of structure and composition attributes. Next, according to an adapted regressive photo interpretation method (Skalos \& Engstova 2010. Andrieu et al. 2011, Plieninger et al. 2012), a duplicate of the 2007 layer was used for the photo interpretation of the preceding (1995) photographs using the same attributes, standards, equipment and photo interpreters for consistency. Basically, polygons in the 2007 map showing changes in classification or shape were modified to obtain the categorical map of 1995. Similarly, a duplicate of the digitized 1995 photo interpretation layer was used for the photo interpretation of the 1958 aerial photographs.

Accuracy of the photo interpretation was assessed by ground verification in September 2008. A randomly selected sample of a minimum of 15 points, each one representative of one digitized patch classified in forest classes, nearest to each afforestation area, was visited and classified on the ground. Comparison of patch compositions based on ground-based and air-survey data gave an overall accuracy of $89 \%$. Mismatching classification was likely the result of tree mortality (dead trees were excluded) and smallsized patches.

The cork oak woodland landscape changes and landscape composition dynamics were

Tab. 1 - Landscape composition at Ulme by land cover classes in the three studied years (1958, 1995 and 2007).

\begin{tabular}{lccc}
\hline \multirow{2}{*}{ Land cover classes } & \multicolumn{3}{c}{ Area in ha (\% of total area) } \\
\cline { 2 - 4 } & $\mathbf{1 9 5 8}$ & $\mathbf{1 9 9 5}$ & $\mathbf{2 0 0 7}$ \\
\hline Cork oak woodlands & $11850(97.3)$ & $6858(56.3)$ & $6833(56.1)$ \\
Cork oak forest & $4819(39.6)$ & $4489(36.9)$ & $3121(25.6)$ \\
Open farmland & $5695(46.7)$ & $1641(13.5)$ & $1544(12.7)$ \\
Shrubland & $1336(11.0)$ & $728(5.9)$ & $2168(17.8)$ \\
Eucalyptus plantation & $266(2.2)$ & $4746(39.0)$ & $4918(40.4)$ \\
Others & $63(0.5)$ & $575(4.7)$ & $428(3.5)$ \\
Total & $12179(100)$ & $12179(100)$ & $12179(100)$ \\
\hline
\end{tabular}

assessed for two consecutive periods, 1958 to 1995 and 1995 to 2007 , based on discrete time transition matrices, where each element represented the proportion of land cover class that changed from one class in time $t$ to another class in time $t+1$ (Baker 1989) for the overall land cover classes. The persistence of each land cover class was calculated as the percentage of the total area maintaining that classification over the whole period (the correspondent to the transition matrix's diagonal element for cork oak woodland landscape).

The evaluation of the impact of wildfires on the landscape composition dynamics was possible only between 1995 and 2007. The burnt area at UL was based on the intersection of the landscape composition map in the year 2007 and the burnt area polygon coverage, commissioned by National Forest Services (AFN 2010 - Fig. 2B), using ArcGIS ${ }^{\mathbb{R}}$ accessed through the software's Image Geoprocessing tools suite. The transition matrix between 1995 and 2007 therefore allowed the comparison of landscape composition in the burnt and unburnt areas (Fig. 2B).

Categorical maps of landscape composition for the three dates were crossed with: (i) the digitized Soil Map of UL (SROA 1972a) at 1:25000 scale using the Portuguese soil classification (Cardoso 1965) and adapted to Reference Soil Groups (WRB 2006 - Fig. 3B); (ii) the Geologic Map of UL, scanned and digitized from the Geologic Map of Portugal (Gonçalves et al. 1979) at 1:50 000 scale (Instituto Geográfico e Cadastral in 1977 - Fig. 3A); and (iii) the Elevation and Slope maps (with 10-m spatial resolution, based on the Digital Terrain Model (DTM) derived from the 1:25 000 topographic maps (CM 342 and 343 from 1991, and 354 and 355 from 1999) from the Portuguese Army Institute (Fig. 2A and Fig. 2B). The area of each vegetation cover class, quantified in hectares and in percentage of total area occupied, was discriminated by soil type or slope class, and was obtained based on the attribute tables of "union" coverage of landscape composition map, in each study year, and the landscape attribute layers (soil type and slope), using $\operatorname{ArcGIS}^{\circledR}$, accessed through the software's Image Geoprocessing tools suite.

\section{Results}

\section{Landscape composition changes}

The landscape mosaic composition at UL strongly changed from 1958 to 2007 (Tab. 1). In 1958 , the landscape was dominated by open farmland (5695 ha, 46.7\%), while in 2007 this cover class occupied only 1544 ha $(12.7 \%)$. This loss mostly occurred during the first study period (1958-1995), as the corresponding area in 1995 was already reduced to 1641 ha $(13.5 \%)$.

The oak forest area declined from 4819 ha 
$(39.6 \%)$ in 1958 to 3121 ha $(25.6 \%)$ in 2007 (Tab. 1). The annual loss of oak forest was much higher in the 1995-2007 period (a total loss of 1368 ha, corresponding to a loss rate of $2.5 \%$ year $^{-1}$ ) than in the 1958-1995 period (a total loss of 330 ha - loss rate: $0.2 \%$ year $\left.^{-1}\right)$. Despite the small changes, intensive transitions related to oak forest occurred in the 1958-1995 period (Tab. 2), as large areas of oak forest were transformed to eucalyptus plantation (1261 ha), whereas a similar extension of open farmland became oak forest (1159 ha). Moreover, the area of oak forest that turned into shrubland (257 ha) was almost counterbalanced by the shrubland area that evolved into oak forest (310 ha).

Eucalyptus plantation occupied only $2.2 \%$ (266 ha) of the landscape in 1958, whereas it was the dominant vegetation cover class in 2007 (40.4\% of the overall land). This land cover class already occupied $39.0 \%$ of the total area in 1995 (Tab. 1), corresponding to an annual area gain of $1 \%$ year $^{-1}$ (i.e., about 121 ha per year).

Shrubland followed an opposite trend over the study period (Tab. 1). Indeed, shrubland area decreased by 608 ha from 1958 to 1995 , while it dramatically increased by 1440 ha over the period 1995-2007. The transition matrix for the 1995-2007 period (Tab. 2) showed that a large percentage of oak forest turned into shrubland (1320 ha, about 29\%) Meanwhile, the percentage of shrubland that turned into eucalyptus plantation and oak forest ( $12 \%$ and $7 \%$, respectively) was much lower than in the previous period.

Changes in open farmland and eucalyptus plantation from 1995 to 2007 were negligible. Open farmland was quite persistent ( $86 \%$ of the initial open farmland was maintained), following the trend exhibited by eucalyptus plantation $(98 \%$ of the 1995 area was maintained in 2007).

\section{Wildfires and landscape composition trends}

In the period 1958-1995, transitions between oak forest and shrubland were compensating, whereas in the 1995-2007 period, a much larger proportion of oak forest area evolved towards shrubland. This net expansion of shrubland mostly occurred in areas affected by wildfires (Fig. 4); given the spatial overlap with the burnt area, shrubland expansion can be interpreted (at least in part) as fire-driven (Tab. 3).

The persistence of cork oak forest in the burnt area was negatively affected by wildfires (Fig. 4), given their higher persistence in the unburnt area (85\%) compared with that observed in the burnt area $(57 \%$ - Tab. $3)$. This decreasing trend in cork oak forest persistence was accompanied by a higher conversion of the burnt cork oak forest to shrubland (1232 ha - about 37\%), while in

Tab. 2 - Transition matrix in Ulme landscape composition for the 1958-1995 (top) and 1995-2007 (bottom) periods. Values are the percentage of the initial area in each land cover class (in brackets the area in hectares).

\begin{tabular}{|c|c|c|c|c|c|}
\hline$\downarrow 1958 / 1995 \rightarrow$ & $\begin{array}{c}\text { Cork oak } \\
\text { forest }\end{array}$ & $\begin{array}{c}\text { Open } \\
\text { farmland }\end{array}$ & Shrubland & $\begin{array}{c}\text { Eucalypt } \\
\text { plantation }\end{array}$ & Others \\
\hline Cork oak forest & $62(2965)$ & $3(141)$ & $5(257)$ & $26(1261)$ & $4(195)$ \\
\hline Open farmland & $21(1159)$ & $26(1467)$ & $4(250)$ & $45(2580)$ & $4(239)$ \\
\hline Shrubland & $23(310)$ & $1(17)$ & $15(193)$ & $55(734)$ & $6(82)$ \\
\hline Eucalypt plantation & $21(50)$ & $5(15)$ & $8(25)$ & $61(163)$ & $5(13)$ \\
\hline Others & $8(5)$ & $3(2)$ & $5(3)$ & $15(10)$ & $69(43)$ \\
\hline$\downarrow 1995 / 2007 \rightarrow$ & $\begin{array}{c}\text { Cork oak } \\
\text { forest }\end{array}$ & $\begin{array}{c}\text { Open } \\
\text { farmland }\end{array}$ & Shrubland & $\begin{array}{c}\text { Eucalypt } \\
\text { plantation }\end{array}$ & Others \\
\hline Cork oak forest & $65(2892)$ & $2(100)$ & $29(1.320)$ & $3(123)$ & $1(54)$ \\
\hline Open farmland & $5(73)$ & $86(1410)$ & $2(41)$ & $3(47)$ & $4(70)$ \\
\hline Shrubland & $7(48)$ & $2(17)$ & $77(560)$ & $12(88)$ & $2(15)$ \\
\hline Eucalypt plantation & $1(40)$ & $0(14)$ & $1(51)$ & $98(4632)$ & $0(9)$ \\
\hline Others & $21(121)$ & $1(6)$ & $36(207)$ & $6(34)$ & $36(207)$ \\
\hline
\end{tabular}

Tab. 3 - Ulme transition matrices for main land cover classes in percentage (\%) of land use area (in brackets: area in hectares) in burnt and unburnt areas. Vegetation cover classes: (OF): Open farmland; (COF): Cork oak forest; (SH): Shrubland; (EP): Eucalyptus plantation.

\begin{tabular}{lcccccccc}
\hline \multirow{2}{2007}{$\rightarrow$} & \multicolumn{4}{c}{ Burnt area } & \multicolumn{4}{c}{ Unburnt area } \\
\cline { 2 - 9 }$\downarrow \mathbf{1 9 9 5}$ & OF & COF & SH & EP & OF & COF & SH & EP \\
\hline OF & $87(664)$ & $5(39)$ & $3(19)$ & $3(23)$ & $85(746)$ & $4(34)$ & $2(21)$ & $3(24)$ \\
COF & $2(69)$ & $57(1916)$ & $37(1232)$ & $3(98)$ & $3(31)$ & $85(980)$ & $8(89)$ & $2(25)$ \\
SH & $3(14)$ & $8(43)$ & $86(463)$ & $2(13)$ & $2(3)$ & $3(5)$ & $51(97)$ & $40(75)$ \\
EP & $1(14)$ & $1(27)$ & $2(51)$ & $96(2973)$ & $0(0)$ & $1(13)$ & $0(0)$ & $99(1664)$ \\
\hline
\end{tabular}

the unburnt area, the correponding conversion rate was only $8 \%$ ( 89 ha).

\section{Landscape mosaic vs. biophysical conditions}

The share of open farmland in 1958 was largely dominant in the bottom of valleys $(72.9 \%)$, areas corresponding to Fluvisols (Tab. 4, Fig. 5). In areas where Stagnic Luvisols are predominant, the proportion of open farmland decreased to $47.7 \%$, while that of cork oak forest reached $40.2 \%$. In areas where Regosols/Cambisols are dominant, open farmland and cork oak forest oc-

Tab. 4 - Areas (ha) of vegetation cover classes by soil type. Values in brackets are the percentage relative to the total (urban areas omitted) soil type area. (a): assumed to occur in areas with slope $<5 \%$; $(*)$ : associated to low extent with Regosols and Cambisols; (**): as sociated to low extent with Stagnic Luvisols and Leptosols.

\begin{tabular}{lccccc}
\hline $\begin{array}{l}\text { Reference } \\
\text { Soil Group }\end{array}$ & Years & $\begin{array}{c}\text { Open } \\
\text { farmland }\end{array}$ & $\begin{array}{c}\text { Cork oak } \\
\text { forest }\end{array}$ & $\begin{array}{c}\text { Eucalyptus } \\
\text { plantation }\end{array}$ & Shrubland \\
\hline Fluvisols & 1958 & $1145(72.9)$ & $357(22.7)$ & $11(0.7)$ & $39(2.5)$ \\
& 1995 & $960(61.1)$ & $297(18.9)$ & $137(8.7)$ & $65(4.1)$ \\
& 2007 & $949(60.4)$ & $204(13.0)$ & $117(7.5)$ & $170(10.8)$ \\
\hline Stagnic & 1958 & $2269(47.7)$ & $1914(40.2)$ & $84(1.8)$ & $479(10.1)$ \\
Luvisols* & 1995 & $301(6.3)$ & $1787(37.5)$ & $2187(46.0)$ & $308(6.7)$ \\
& 2007 & $252(5.3)$ & $1311(27.6)$ & $2272(47.8)$ & $803(16.9)$ \\
\hline Regosols/ & 1958 & $2258(38.9)$ & $2541(43.8)$ & $171(2.9)$ & $818(14.1)$ \\
Cambisols** $^{*}$ & 1995 & $372(6.4)$ & $2403(41.4)$ & $2420(41.7)$ & $354(6.1)$ \\
& 2007 & $334(5.8)$ & $1606(27.7)$ & $2527(43.5)$ & $1193(20.6)$ \\
\hline
\end{tabular}




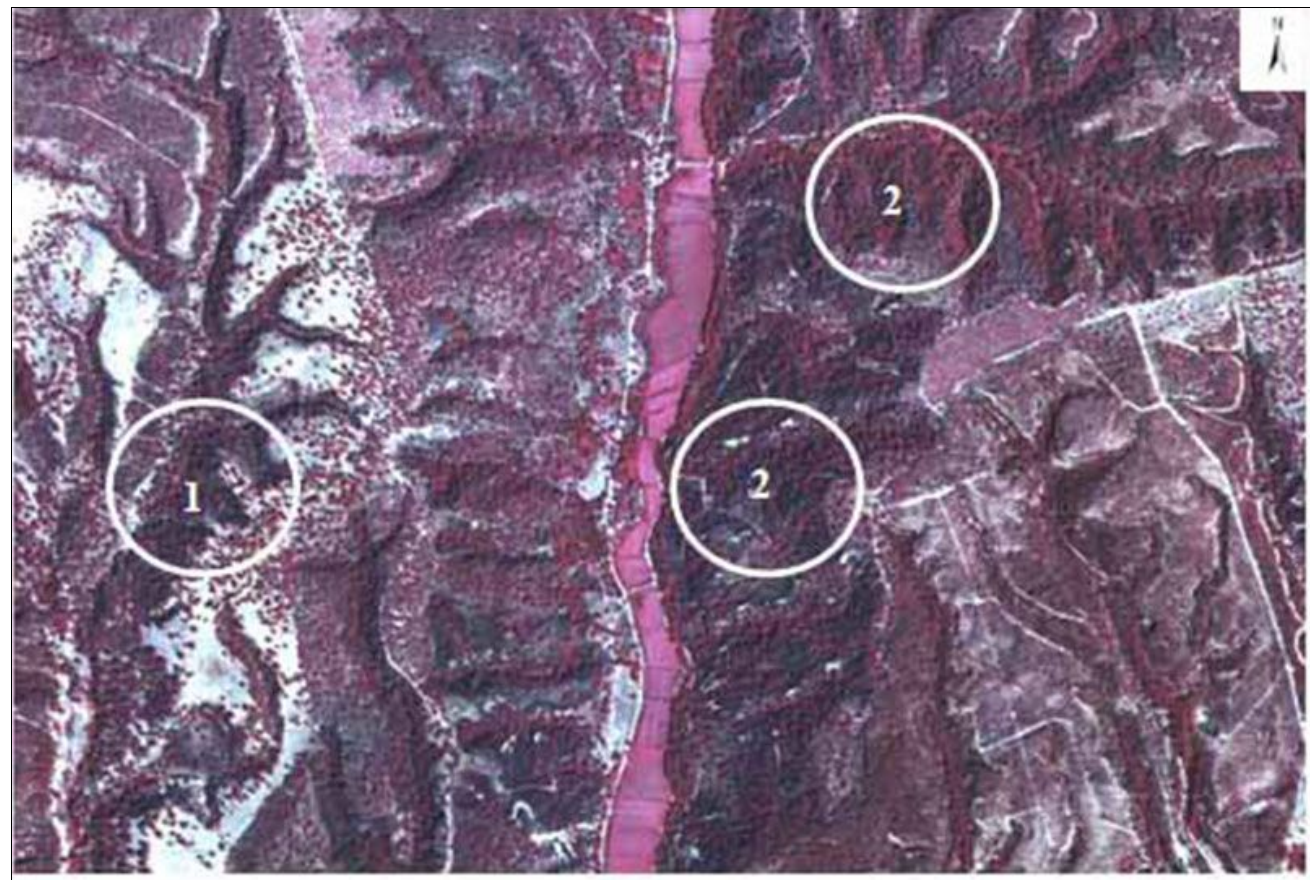

Fig. 4 - Aerial photographs of Ulme area in 1995 (colour near infrared - top) and 2007 (true RGB colour - bottom) showing land use changes in the area burnt in 2003 (approximate scale 1:10.000): (1) In 1995, the steeper slopes and gullies were covered with cork oaks (in dark red tones), and in 2007 covered with shrubland (dark green tones); (2) Cork oak woodland areas in 1995 turned into shrubland in 2007.

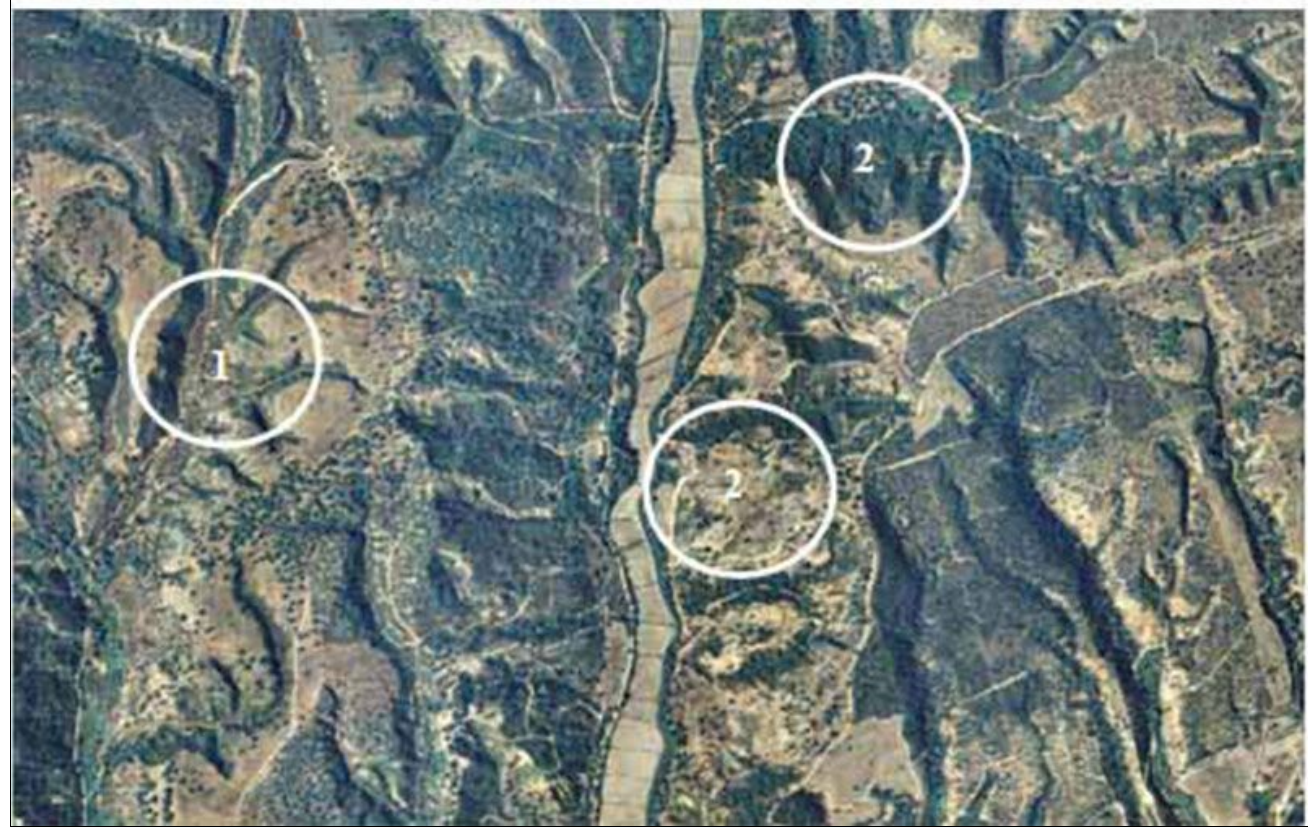

5). A similar trend was observed for the share of shrubland, which varied from 2.5 (bottom of valleys) to $18.3 \%$ (in areas with a slope $>25 \%$ ).

The landscape mosaic pattern was strongly changed in 1995, following the impressive expansion of eucalyptus plantations. This expansion was relatively small only in the bottom of valleys $(8.0 \%$ - Tab. 4$)$, as in the flat tops of gently undulating areas (slope $<5 \%$ ), the share of eucalyptus plantation in 1995 reached $54.9 \%$ (Tab. 5). A strong increment in the share of eucalyptus plantation also occurred in areas corresponding to the 5-12, $12-25$, and $>25 \%$ slope classes $(44.8,39.2$, and $34.1 \%$, respectively - Tab. 5). Only in the $12-25$ and $>25 \%$ slope classes, where open farmland showed a negligible presence, the share of eucalyptus plantation was not dominant in comparison to cork oak forest, which occupied a share of 44.8 and $52.7 \%$, respectively (Tab. 5).

In the 1958-1995 period, the cork oak forest area dropped by $16.8 \%$ in the areas corresponding to Fluvisols (Tab. 4). In contrast, the area of cork oak forest in the same period increased by $17.3 \%$ in areas with a slope of $<5 \%$, but corresponding to flat top areas (Tab. 5). In other slope classes, the cork oak forest area decreased by 3.4, 13.9, and $13.6 \%$ for the $5-12,12-25$, and $>25 \%$ slope classes, respectively. Variations in the share of open farmland and eucalyptus plantation from 1958 to 1995 were small in areas corresponding to Fluvisols (Tab. 4), compared with those of Stagnic Luvisols and Regosols/Cambisols. Differences with respect to these soil types were negligible.

The persistence of shrubland in the 19581995 period (15\% - Tab. 2) was lower than that exhibited by open farmland (26\%), and especially by cork oak forest $(62 \%)$. The strong reduction in the share of shrubland was observed in all slope classes, but it was much greater in the steeper classes (Tab. 5), where the relative reduction was the highest. As some of these areas turned into eucalyptus plantation (Fig. 5), it is clear that the ex- 
pansion of eucalyptus was responsible for the reduction in oak forest and shrubland vegetation cover classes. The highest reduction in the share of shrubland occurred in areas corresponding to Regosols/Cambisols (Tab. $4)$.

Landscape changes from 1995 to 2007 were small regarding open farmland and eucalyptus plantation (Tab. 1), and fire did not seem to affect the persistence of these vegetation classes (Tab. 3). Landscape mosaic changes, as aforementioned, were mostly associated with cork oak decrease (and shrubland increase), driven by wildfire, which promoted faster changes in oak forest cover in the 1995-2007 period than those promoted by the eucalyptus plantation in the previous period (1958-1995).

Fig. 5 - Aerial photographs of Ulme in 1958 (black and white - top) and 1995 (near infrared colour - bottom) showing landscape features and land use changes (approximate scale 1:10.000). (1): new afforestation area with cork oak in former open farmland (in 1958) that turned into a mature cork oak forest in 1995; (2) eucalyptus forest in 1995 established in former open farmland (in 1958), without (2a) and with olive groves

(2b)
Tab. 5 - Areas (ha) of vegetation cover classes by slope classes. Values in brackets are the percentage relative to the total area corresponding to each slope class. (a): areas other than alluvial areas.

\begin{tabular}{cccccc}
\hline $\begin{array}{c}\text { Slope class } \\
(\%)\end{array}$ & Year & $\begin{array}{c}\text { Open } \\
\text { farmland }\end{array}$ & $\begin{array}{c}\text { Cork oak } \\
\text { forest }\end{array}$ & $\begin{array}{c}\text { Eucalyptus } \\
\text { plantation }\end{array}$ & Shrubland \\
\hline$<5^{(\mathrm{a})}$ & 1958 & $1804(62.3)$ & $787(27.2)$ & $97(3.3)$ & $209(7.2)$ \\
& 1995 & $263(9.0)$ & $923(32.8)$ & $1501(54.9)$ & $121(4.3)$ \\
& 2007 & $230(8.1)$ & $702(24.8)$ & $1546(54.7)$ & $351(12.4)$ \\
\hline $5-12$ & 1958 & $1353(49.9)$ & $981(36.2)$ & $74(2.7)$ & $289(10.7)$ \\
& 1995 & $259(9.5)$ & $947(34.9)$ & $1214(44.8)$ & $164(6.0)$ \\
& 2007 & $228(8.4)$ & $701(25.9)$ & $1250(46.1)$ & $436(16.1)$ \\
\hline $12-25$ & 1958 & $1176(30.4)$ & $2013(52.1)$ & $71(1.8)$ & $596(15.4)$ \\
& 1995 & $149(3.9)$ & $1733(44.8)$ & $1514(39.2)$ & $292(7.6)$ \\
& 2007 & $131(3.4)$ & $1152(29.8)$ & $1587(41.0)$ & $902(23.3)$ \\
\hline 25 & 1958 & $216(19.4)$ & $680(60.9)$ & $14(1.2)$ & $204(18.3)$ \\
& 1995 & $10(0.9)$ & $588(52.7)$ & $381(34.1)$ & $87(7.8)$ \\
& 2007 & $6(0.5)$ & $362(32.4)$ & $419(37.5)$ & $310(27.8)$ \\
\hline
\end{tabular}
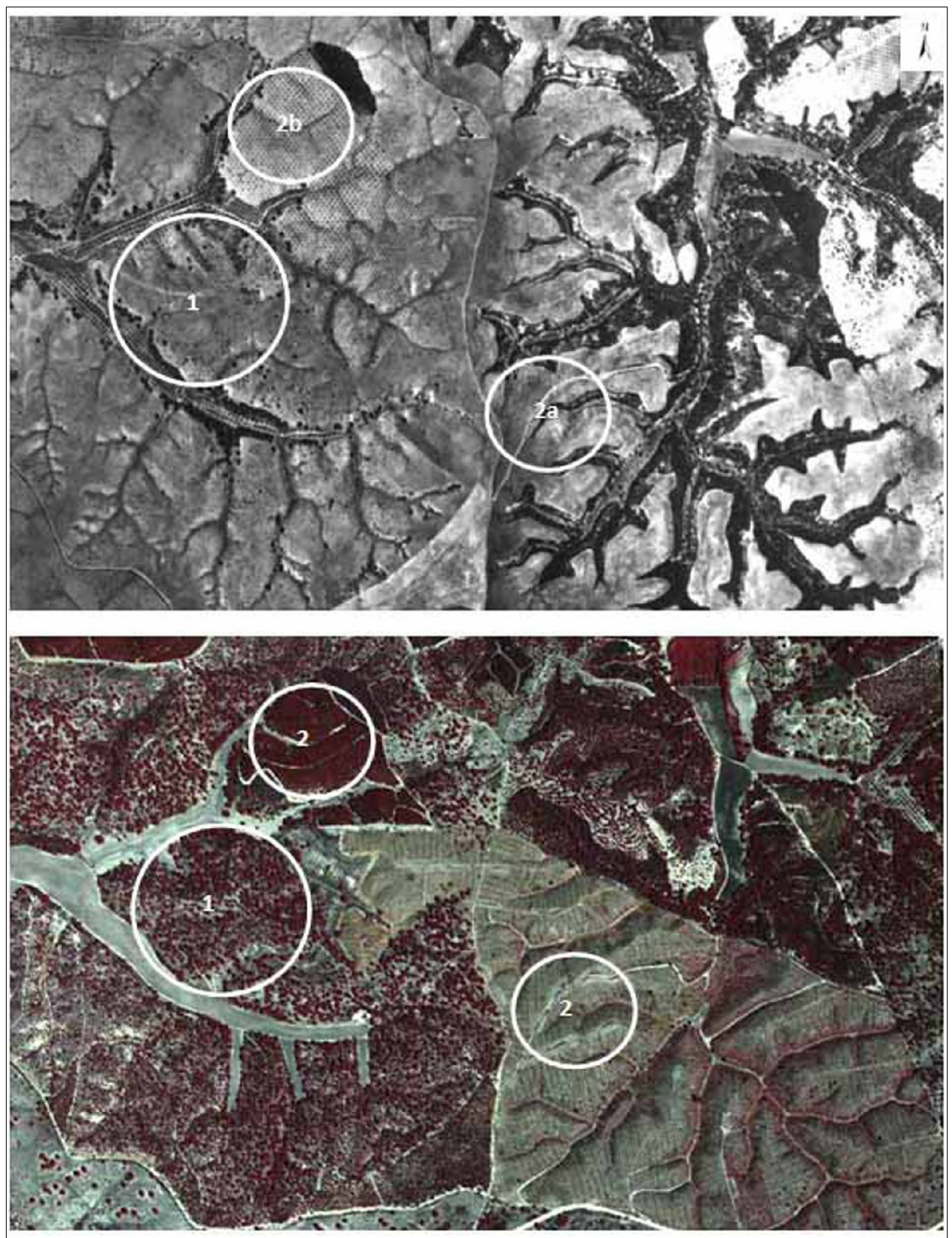


\section{Discussion}

\section{Change in landscape composition}

The strong decline in open farmland, mostly occurring in the first study period (19581995), is associated with a long-standing socio-economic driver in the Chamusca municipality, such as the declining availability of labor force in agriculture. In fact, employment in this municipality in the farming sector (in standard working units, SWU) declined by $75 \%$, about 3579 SWU (from 4798 SWU in 1960 to 1219 SWU in $1999 / 2000$. GPPAA 2003).

The transition matrix obtained in this study was mostly dominated by the transition rate underlying the decline of open farmland and the increment of eucalyptus plantations ( $\mathrm{Tab}$ 2 ). This is in accordance to Salinas \& Marques (1985) who reported that, since 1970, in association with the abandonment of agricultural activities in southern Portugal, open farmland and open (oak) forest formations were largely replaced by eucalyptus plantations. Similar occurrences were reported for southern Extremadura and western Andalucia (Spain - Regato-Pajares et al. 2004 Schröder 2011). Moreover, such transitions are also in agreement with those reported by Moreira et al. (2001) for wetter areas in northern Portugal, by Pinto-Correia \& Vos (2004) and Costa et al. (2011) for dryer inland areas in southern Portugal, and by Teixido et al. (2010) for the Galician region (northwestern Spain), where forest expansion through afforestation and vegetation succession was associated with agricultural abandonment

According to the transition matrix for the 1958-1995 period, open farmland only persisted in $26 \%$ of its initial area, being partly transformed into eucalyptus plantation (and to a lesser extent to cork oak forest - Tab. 2) On the other hand, eucalyptus plantations were established on open farmland and also on shrubland and oak forests, showing a conversion percentage of initial area transition of $45 \%, 55 \%$, and $26 \%$, respectively. This large expansion of eucalyptus plantations is similar to the dynamics of rural areas in northwestern Spain (Atlantic-temperate climate), where the eucalyptus plantations were introduced in the second half of the $20^{\text {th }}$ century, along with farming abandonment (Teixido et al. 2010).

Despite large areas of oak forest being turned into eucalyptus plantation, a low overall annual loss in oak forest area occurred during the 1958-1995 period. This small loss was the result of intensive transitions related to oak forest occurred in this period (Tab. 2), with large areas of open farmland becoming oak forest, and with counterbalancing transformation of shrubland to oak forest and vice versa.

Shrubland was reduced by half (loss rate:
$0.2 \%$ year $^{-1}$ ) within the $1958-1995$ period, as it was a source for other land cover classes, specially eucalyptus plantation (55\%) and oak forest $(23 \%$ - see Tab. 2). This trend, during the 1958-1995 period is in contrast to the results reported by Costa et al. (unpublished) for the same period for other areas in southern Portugal (Alcoutim and S. Bartolomeu da Serra), where shrubland increased by $17.7 \%$ year $^{-1}$ (corresponding to an increase of 128 ha year $\left.^{-1}\right)$ and $4.6 \%$ year $^{-1}(3$ ha year $\left.{ }^{-1}\right)$, respectively. These trends were mainly driven by adverse ecological conditions to new afforestions with eucalyptus, the abandonment of agriculture in marginal lands (in Alcoutim), and forest management abandonment and abnormal tree mortality (in S. Bartolomeu da Serra).

\section{Landscape mosaic vs. biophysical conditions}

The large share of open farmland (annual cereal crops and olive groves, $46.7 \%$ - Tab. 1) in 1958 was associated with the Wheat Campaign in Portugal (1929-1937), an agricultural policy that provided direct support to the enhancement of crop cultivation and conversion of forest and shrubland to arable uses, despite soil and land constraints (Baptista 2010). However, the UL landscape mosaic in 1958 was also strongly associated with biophysical conditions, namely the slope (see Fig. 5 and Tab. 5). The share of open farmland was largely dominant in valley floors and top flat areas. Conversely, the share of cork oak forest and shrubland was much greater in steep undulated areas surrounding watercourses (see Tab. 5). This pattern may be associated with less human activities in the latter areas. A similar scenario was reported by Acácio et al. (2009) for southern Portugal (Serra do Caldeirão), where this trend was associated with limitations to agriculture imposed by steep slopes and thin soils (SROA 1972b - Fig. 5).

Land cover classes were also dependent on soil type (Tab. 4). The largest share of open farmland was observed on Fluvisols in the bottom of valleys, where soil depth and moisture regime are suitable for intensive agriculture (SROA 1972a, 1972b). In areas where Stagnic Luvisols are predominant, the difference between the proportion of open farmland (reduced to 47.7\%) and cork oak forest (reaching $40.2 \%$ ) is explained by the fact that these soils occur on different slope conditions (Fig. 3B), showing limitations regarding drainage and water availability. In areas where Regosols/Cambisols are dominant, the decrease in the share of open farmland (only $38.9 \%$ ) may be explained by the steeper slopes where these soils occur, which are also associated with soil depth limitations and erosion risks (SROA 1972a, 1972b).

Our results suggest that differences in the share of vegetation cover classes among soil types may be mostly due to slope, confirming our preliminary hypothesis. Indeed, terrain slope was apparently more discriminating for vegetation cover than soil type. In short, cork oak woodlands in 1958 showed a spatial arrangement strongly framed by biophysical characteristics closely associated with the spatial arrangement of the network of watercourses (Fig. 5). However, such areas might constitute safe places for the maintenance of oak woodlands, assuring cork oak regeneration and the potential for later expansion through ecological succession and the colonization of neighboring areas (Pausas et al. 2006, Pons \& Pausas 2006, Plieninger 2007). According to the landscape composition, the cork oak forest in 1958 was already restricted to areas with the strongest limitations for farming (Tab. $5)$.

The large expansion of eucalyptus plantation from 1958 to 1995 at UL showed a strong association with landscape biophysical conditions, with its share reduced with the increase in slope. For instance, the increment in the bottom of valleys was small, as these areas are suitable for agriculture. In contrast, in the flat top areas (slope $<5 \%$ ), the share of eucalyptus plantation reached $54.9 \%$ (in 1995). A strong increment in the share of eucalyptus plantation also occurred in the undulated areas (Tab. 5). However, the increase in cork oak forest also took place in the areas where the share of eucalyptus plantation was the highest (Tab. 5). Therefore, at UL in the post-Wheat Campaign period (from the early 1960s forward), both eucalyptus plantations (on a larger scale) and cork oak forests (on a smaller scale) displaced open farmland in top flat areas, where Stagnic Luvisols were dominant and the conditions were more suitable for profitable fast-growing eucalyptus plantations.

Variations in the share of open farmland and eucalyptus plantations from 1958 to 1995 were small in areas corresponding to Fluvisols (Tab. 4), compared with those of Stagnic Luvisols and Regosols/Cambisols. Differences with respect to these soil types were negligible. Therefore, the change in the pattern of these vegetation classes seems to be mainly associated with terrain slope rather than soil type, confirming our first hypothesis.

The persistence of shrubland in the 19581995 period was lower than that exhibited by open farmland and especially that exhibited by cork oak forest. The strong reduction in the share of shrubland was observed in all slope classes, but was much greater in the steeper classes (Tab. 5). Shrubland, as well as oak forest, are more common on steepest slopes closely associated with the network of watercourses (Fig. 5). As some of these areas turned into eucalyptus plantation (Fig. 5), it 
may be inferred that the expansion of eucalyptus was responsible for the reduction in oak forest and shrubland vegetation cover classes. The highest reduction in the share of shrubland in areas corresponding to $\mathrm{Re}$ gosols/Cambisols (Tab. 4) may be associated with the higher slope in the parts of the landscape where these soils occur.

Eucalyptus was already present in the study area in 1958 by the farmers' initiative (Mendes et al. 2004). The large availability of open farmland areas, combined with suitable ecological conditions, species' high productivity (Goes 1991), and the use of proper silvicultural techniques overcoming soil and terrain constraints (Magalhães 2000) turned the eucalyptus into an extremely attractive option (Fig. 5). However, eucalyptus plantation was also widely established in areas with steeper slopes (Tab. 5). Such marginal areas are free from grazing, and may constitute cork oak regeneration hotspots, which are crucial to ensure the sustainability of this ecosystem (Pons \& Pausas 2006). However such landscape spatial arrangement and functions were partially eliminated by eucalyptus plantations, reducing also the landscape diversity.

The massive establishment of eucalyptus plantations, however, mostly occurred until the end of the 1980s, when constraining rules for afforestation with fast-growing species such as eucalyptus were issued. In fact the Ministerial Order no. 175/88 (May $17^{\text {th }}$ 1988) established that afforestation with these species is conditioned to previous authorization by the Forest Services. Furthermore the Ministerial Order no. 528/89 (Nov $11^{\text {th }}$ 1989) defined specific norms and constraints for plantations of fast-growing species, namely the obligation of oak woodland preservation, in order to keep former vegetation in burnt areas and preserve natural vegetation and functions in main watercourses.

\section{Wildfires and landscape composition trends}

Landscape composition in 2007 was shaped by changes mainly occurring in the period 1958-1995 and by fire occurrence (in 2003). Wildfire did not seem to affect the persistence of open farmland and eucalyptus plantation in the period 1995-2007 (Tab. 3) Landscape mosaic changes were mostly associated with cork oak decrease (and shrubland increase) driven by wildfire (Fig. 2B, Tab. 3), which determined in the period 1995-2007 faster changes in oak forest cover than those caused by eucalyptus plantations in the previous period (1958-1995).

The transitions between oak forest and shrubland were balanced in 1958-1995, whereas in 1995-2007, a much larger share of oak forest area evolved towards shrubland. The persistence of cork oak forest was negatively affected by wildfires (Fig. 4), gi- ven the higher persistence in the unburnt area compared with that observed in the burnt area (Tab. 3). This decrease in cork oak forest persistence was accompanied by a conversion of (burnt) cork oak forest to shrubland (Fig. 4). Therefore, in the 19952007 period fire accelerated the change from oak forest to shrubland areas, following the typical land cover change pattern in burnt areas of the Mediterranean region, with a fire-driven decrease in the persistence of forests (San-Miguel-Ayans et al. 2012). Also, this trend agrees with that reported by Acácio et al. (2009) for open oak forest areas in southern Portugal subjected to recurrent fire events.

Changes caused by fire, however, seem to be also dependent on landscape features, as the effect of fire devastation was much less remarkable in the steeper slopes along watercourses than in other areas (Fig. 4). Slopes might act as a buffer regarding wildfire effects, contributing to the recovery of oak forest in these Mediterranean landscapes. Such considerations comply with our second hypothesis on higher resilience of cork oak vegetation to wildfires than to eucalyptus expansion. Furthermore, the effects of fire on the balance between shrubland and oak forests were strongly diminished on slopes (Fig. 4), where a faster ecological succession may be ensured. This is apparently in agreement with the findings of Acácio et al. (2009), who reported lower losses of cork oak forests on steeper slopes in southern Portugal. Although these authors emphasized the effect of a reduced human intervention on steeper slopes, we hypothesized that such evidence may also be related to the biophysical features of the studied areas affecting fire regimes and fire events (Catry et al. 2012).

It should be emphasized, however, that shrubland increment can occur in the absence of fires, as reported by Costa et al. (2011). Local socio-economic conditions, different management systems (e.g., grazing intensities) and other causes of oak decline may explain the conversion of oak forest to shrubland. In another region (Alcoutim) located in a drier area, shrubland significantly decreased in the period 1995-2007 as compared to 1958-1995, since it was replaced by new pine plantations (Costa et al., unpublished).

Our results suggest that landscape changes in the study area were mostly driven by economic factors occurred from 1958 to 1995 ; later changes were mostly associated with the effects of wildfires.

\section{Conclusions}

In the studied cork oak woodland landscape, open farmland and shrubland drastically declined from 1958 to 1995 , while eucalyptus plantation exhibited a dramatic ex- pansion. Although large areas of cork oak forest turned into eucalyptus plantation, the net loss of oak forest was low and counterbalanced by its increment on former open farmland. These changes were mainly driven by the large availability of open farmland and the high profitability of eucalyptus plantation when compared, from a shortterm perspective, with both rain-fed agriculture and cork oak afforestation. The expansion of eucalyptus plantation from 1958 to 1995 led to shrinkage of shrubland and oak forest areas. Landscape changes in the period 1995-2007 were strongly affected by wildfires and mostly restricted to the shift from oak forest to shrubland. Trends of landscape composition changes after the fire events may be related to landowners' decisions, due to legal constraints ruling the plantation of fast-growing species in burnt areas. Landscape composition changes were also driven by biophysical conditions, due to limitations imposed by soils and steep slopes surrounding watercourses. Slope may play a major role in the landscape change process compared with soil type, as it constitutes a strong limitation for human intervention.

Our study demonstrates that monitoring the landscape dynamics in a Mediterranean region allows the assessment of the impact of long-term socio-economic strategies on oak woodlands. However, extreme events such as wildfires, existing laws and regulations aimed to the conservation of oak woodlands, and the biophysical features of the landscape also play a crucial role in the dynamics of cork oak forests.

\section{Acknowledgements}

We thank Filipa Vidas for its contribution in the geo-referencing of the Geological Map. We acknowledge two anonymous reviewers for their comments on an earlier version of the manuscript.

\section{References}

Acácio V, Holmgren M, Rego F, Moreira F, Mohren GMJ (2009). Are drought and wildfires turning Mediterranean cork oak forests into persistent shrublands? Agroforestry Systems 76: 389-400. - doi: 10.1007/s10457-008-9165-y

AFN (2010). Mapa de áreas ardidas [Burned Area Map]. Autoridade Florestal Nacional, Lisbon, Portugal. [online] URL: http://www.afn.min-agricultura.pt/portal/dudf/cartografia/ma-

pas-de-areas-ardidas

Andrieu E, Ladet S, Heintz W, Deconchat M (2011). History and spatial complexity of deforestation and logging in small private forests. Landscape and Urban Planning 103: 109-117. doi: 10.1016/j.landurbplan.2011.06.005

Baptista FO (2010). Alentejo: a questão da terra [Alentejo, the question of land]. 100 Luz, Lisbon, Portugal. [in Portuguese]

Baker WL (1989). A review of models of landscape change. Landscape Ecology 2 (2):111-133. 


\section{- doi: 10.1007/BF00137155}

Bugalho MN, Caldeira MC, Pereira JS, Aronson J, Pausas JG (2011). Mediterranean cork oak savannas require human use to sustain biodiversity and ecosystem services. Frontiers in Ecology and the Environment 9: 278-286. - doi: 10.1890/100 084

Cano F, Navarro RM, Ferrer AG (2003). Evolución de la cubierta de alcornoque en un monte afectado por la seca (La Alcaidesa-Cádiz) mediante una secuencia de fotografías aéreas $[\mathrm{Ca}$ nopy cover change in endangered oak forests (Cádiz) based on an aerial photo sequence]. Ecologia 17:131-144. [in Spanish]

Capelo J, Mesquita S, Costa JC, Ribeiro S, Arsénio $\mathrm{P}$, Neto $\mathrm{C}$, Monteiro-Henriques $\mathrm{T}$, Aguiar C, Honrado J, Espírito-Santo D, Lousã M (2007). A methodological approach to potential vegetation modeling using GIS techniques and phytosociological expert-knowledge: application to mainland Portugal. Phytocoenologia 37 (3/4): 399-415. - doi: 10.1127/0340-269X/2007/00370399

Cardoso JVC (1965). Os solos de Portugal. Sua classificação, caracterização e génese. 1 - A Sul do rio Tejo [The soils of Portugal. Classification, characterization and genesis. 1 - South of the Tagus river]. DGSA, Lisboa, Portugal. [in Portuguese]

Catry FX, Moreira F, Cardillo E, Pausas JG (2012). Post-fire management of cork oak forests. In: "Post-fire management and restoration of Southern European forests" (Moreira F, Arianoutsou M, Corona P, De las Heras J eds). Series Managing Forest Ecosystems, vol. 24, Springer, London, UK, pp. 195-222.

Costa A, Madeira M, Oliveira AC (2008). The relationship between cork oak growth patterns and soil, slope and drainage in a cork oak woodland in southern Portugal. Forest Ecology and Management 255: 1525-1535. - doi: 10.1016/j.foreco. 2007.11.008

Costa A, Pereira H, Madeira M (2009). Landscape dynamics in endangered cork oak woodlands in southwestern Portugal (1958-2005). Agroforestry Systems 77: 83-96. - doi: 10.1007/s10457-0099212-3

Costa A, Pereira H, Madeira M (2010). Analysis of spatial patterns of oak decline in cork oak woodlands in Mediterranean conditions. Annals of Forest Sciences 67: 2 - doi: 10.1051/forest/ 2009097

Costa A, Madeira M (2011). Assessment of Mediterranean evergreen oak (Quercus suber L.) woodlands loss. Consequences of climate change effects: a case study at south-western Portugal. In: Proceedings of the "Global Conference on Global Warming". Lisbon (Portugal) 11-14 July 2011. [online] URL: http://www.cge.uevora.pt/ GCGW/presentations/97-127-1-RV.pdf

Costa A, Madeira M, Santos JL, Oliveira A (2011). Change and dynamics in Mediterranean evergreen oak woodlands landscapes of southwestern Iberian peninsula. Landscape and Urban Planning 102 (3): 164-176. - doi: 10.1016/j. landurbplan.2011.04.002
DGRF (2007). Resultados do Inventário Florestal Nacional 2005/06 [Results from the National Forest Inventory 2005/06]. Inventário Florestal Nacional, Direcção-Geral dos Recursos Florestais, Lisboa, Portugal. [in Portuguese]

Goes E (1991). A floresta portuguesa - sua import'ncia e descrição das espécies de maior interesse [Portuguese forest - its importance and description of major species]. Portucel, Lisbon, Portugal, pp. 159. [in Portuguese]

Gonçalves F, Zbyszevski G, Carvalhosa A, Coelho AP (1979). Carta Geológica de Portugal na Escala 1/50.000. Notícia Explicativa da Folha 27-D (Abrantes) [Geological Map of Portugal, Scale 1/50.000. Explanatory News Sheet 27-D (Abrantes)]. Serviços Geológicos de Portugal, Lisboa, Portugal. [in Portuguese]

GPPAA (2003). Portugal rural: territórios e din'micas [Rural Portugal: territory and dinamics]. Gabinete de Planeamento e Políticas Agro-alimentares, ISA, Portugal. [CD-ROM, in Portuguese]

Huntsinger L, Bartolome JW (1992). Ecological dynamics of Quercus dominated woodlands in California and southern Spain: a state-transition model. Vegetatio 99-100 (1): 299-305. - doi: 10.1007/BF00118237

IA (2010). Atlas do Ambiente [Digital Atlas of the Environment]. Agência Portuguesa do Ambiente. [online] URL: http://sniamb.apambiente.pt/web atlas/

Joffre R, Rambal S, Ratte JP (1999). The dehesa system of southern Spain and Portugal as a natural ecosystem mimic. Agroforestry Systems 45 (3): 57-79. - doi: 10.1023/A:1006259402496

Magalhães MCS (2000). Efeitos de técnicas de preparação do solo e gestão dos resíduos org'nicos em características físico-químicas do solo de plantações florestais [Effects of preparation techniques of soil and management of organic waste on physico-chemical characteristics of the soil of forest plantations]. $\mathrm{PhD}$ thesis, Universidade Técnica de Lisboa, Instituto Superior de Agronomia, Lisbon, Portugal, pp. 170. [in Portuguese]

Manning AD, Fischer J, Lindenmayer DB (2006). Scattered trees are keystones - Implications for conservation. Biological Conservation 132: 311321. - doi: 10.1016/j.biocon.2006.04.023

Martínez S, Ramil P, Chuvieco E (2010). Monitoring loss of biodiversity in cultural landscapes. New methodology based on satellite data. Landscape and Urban Planning 94: 127-140. - doi: 10.1016/j.landurbplan.2009.08.006

Mendes AMSC, Dias RARS (2001). Financial instruments of forest policy in Portugal in the ' $80 \mathrm{~s}$ and '90s. Faculty of Economics and Management, Portuguese Catholic University, Porto, Portugal. [online] URL: http://www.metla.fi/ $\mathrm{eu} / \mathrm{cost} / \mathrm{e} 19 /$

Mendes AMSC, Feliciano D, Tavares M, Dias R (2004). The Portuguese forests: country level report delivered to the EFFEProject - Evaluating financing of forestry in Europe. Faculty of Economics and Management, Portuguese Catholic University, Porto, Portugal.
Myers N, Mittermeier RA, Mittermeier CG (2000). Biodiversity hotspots for conservation priorities. Nature 403: 853-858. - doi: 10.1038/ 35002501

Moreira F, Rego FC, Ferreira PG (2001). Temporal (1958-1995) pattern of change in a cultural landscape of northwestern Portugal: implications for fire occurrence. Landscape Ecology 16: $557-$ 567. - doi: 10.1023/A:1013130528470

Pereira PM, Fonseca MP (2003). Nature vs. nurture: the making of the montado ecosystem. Conservation Ecology 7 (3): 7. [online] URL: http:// www.ecologyandsociety.org/vol7/iss3/art7/

Pinto-Correia T (2000). Future development in Portuguese rural areas: how to manage agricultural support for landscape conservation? Landscape and Urban Planning 50: 95-106. - doi: 10.1016/S0169-2046(00)00082-7

Pinto-Correia T, Vos W (2004). Multifunctionality in Mediterranean landscapes - past and future. In: "The New Dimensions of the European Landscape" (Jongman R ed). EU Frontis Series, Springer, Wageningen, The Netherlands, pp. 135-164.

Plieninger T (2006). Habitat loss, fragmentation and alteration - quantifying the impact of land use changes on a Spanish dehesa landscape by the use of aerial photographs and GIS. Landscape Ecology 21: 91-105. - doi: 10.1007/s109 80-005-8294-1

Plieninger T (2007). Compatibility of livestock grazing with stand regeneration in Mediterranean holm oak parklands. Journal for Nature Conservation 15(1): 1-9. - doi: 10.1016/j.jnc.2005.09.0 02

Plieninger T, Bieling C (2012). Connecting cultural landscapes to resilience. In: "Resilience and the cultural landscape. Understanding and managing in human-shaped environments" (Plieninger $\mathrm{T}$, Boieling $\mathrm{C}$ eds). Cambridge University Press, Cambridge, UK, pp. 3-26.

Plieninger T, Schleyer C, Mantel M, Hostert P (2012). Is there a forest transition outside forests? Trajectories of farm trees and effects on ecosystem services in an agricultural landscape in eastern Germany. Land Use Policy 29: 233234. - doi: 10.1016/j.landusepol.2011.06.011

Pausas JG, Ribeiro E, Dias SG, Pons J, Beseler C (2006). Regeneration of a marginal Quercus suber forest in the eastern Iberian peninsula. Journal of Vegetation Science 17: 729-738. doi: 10.1111/j.1654-1103.2006.tb02496.x

Pons J, Pausas JG (2006). Oak regeneration in heterogeneous landscapes: the case of fragmented Quercus suber forests in the eastern Iberian peninsula. Forest Ecology and Management 231: 196-204. - doi: 10.1016/j.foreco.2006.05.049

Regato-Pajares P, Jiménez-Caballero S, Castejón M, Elena-Rosselló R (2004). Recent landscape evolution in dehesa woodlands of western Spain. In: "Recent dynamics of the Mediterranean vegetation and landscape" (Mazzoleni S, Di Pasquale G, Mulligan M, Di Martino P, Rego F eds). John Wiley and Sons, Chichester, UK, pp. 57-72.

Salinas F, Marques H (1985). A expansão do eu- 
calipto em Portugal: seu enquadramento legal [The expansion of eucalyptus plantations in Portugal: legal framework]. In: Proceedings of the "I Congresso sobre o Alentejo: semeando novos rumos". Évora (Portugal) October 1985. Associação dos Municípios do Distrito de Beja, Beja, Portugal, vol. 2, pp. 590-594. [in Portuguese]

San-Miguel-Ayans J, Rodrigues M, Oliveira SS, Pacheco CK, Moreira F, Duguy B, Camia A (2012). Land cover change and fire regime in the European Mediterranean region. In: "Post-fire management and restoration of Southern European forests" (Moreira F, Arianoutsou M, Corona P, De las Heras J eds). Series Managing Forest Ecosystems, vol. 24, Springer, London, UK, pp.21-43.

Santos MJ, Thorne J (2010). Comparing culture and ecology: conservation planning of oak woodlands in Mediterranean landscapes of Portugal and California. Environmental Conservation 37 (2): 155-168. - doi: 10.1017/S0376892910000 238

Schröder C (2011). Land use dynamics in the dehesas in the Sierra Morena (Spain): the role of diverse management strategies to cope with the drivers of change. European Countryside 2: 93110.

Skalos J, Engstova B (2010). Methodology for mapping non-forest wood elements using historic cadastral maps and aerial photographs as a basis for management. Journal of Environmental Management 91: 831-843. - doi: 10.1016/j.jenvman.2009.10.013

SROA (1972a). Serviço de Reconhecimento e de Ordenamento Agrário - Carta de Solos de Portugal na Escala 1/50 000, folha 27-D [Agricultural Recognition and Planning Service - Soil Map of Portugal in Scale 1/50 000, sheet 27-D]. Serviço de Reconhecimento e de Ordenamento Agrário, Secretaria de Estado da Agricultura, Lisboa, Portugal. [in Portuguese]

SROA (1972b). Serviço de Reconhecimento e de Ordenamento Agrário - Carta de Capacidade de Uso do Solo na Escala 1/50 000, folha 27-D [Agricultural Recognition and Planning Service Map of Land use Capability of Portugal in Scale 1/50 000, sheet 27-D]. Serviço de Reconhecimento e de Ordenamento Agrário, Secretaria de
Estado da Agricultura, Lisboa, Portugal. [in Portuguese]

Teixido AL, Quintanilla LG, Carreño F, Gutiérrez D (2010). Impacts of changes in land use and fragmentation patterns on Atlantic coastal forests in northern Spain. Journal of Environmental Management 91: 879-886. - doi: 10.1016/j.jenvman.2009.11.004

Urbieta IR, Zavala MA, Marañón T (2008). Human and non-human determinants of forest composition in southern Spain: evidence of shifts towards cork oak dominance as a result of management over the past century. Journal of Biogeography 35: 688-1700. - doi: 10.1111/j.1365-26 99.2008.01914.x

Vallejo R, Aronson J, Pausas JG, Cortina J (2006). Restoration of Mediterranean woodlands. In: "Restoration ecology: The new frontier" (Van Andel J, Aronson J eds), Blackwell Science, Oxford, UK, pp. 193-207.

WRB (2006). World reference base for soil resources. A framework for international classification, correlation and communication. World Soil Reports no. 103, FAO, Rome, Italy. 